Prepared in cooperation with the State of Hawaii Department of Transportation

\title{
Geospatial Datasets for Watershed Delineation and Characterization Used in the Hawaii StreamStats Web Application
}

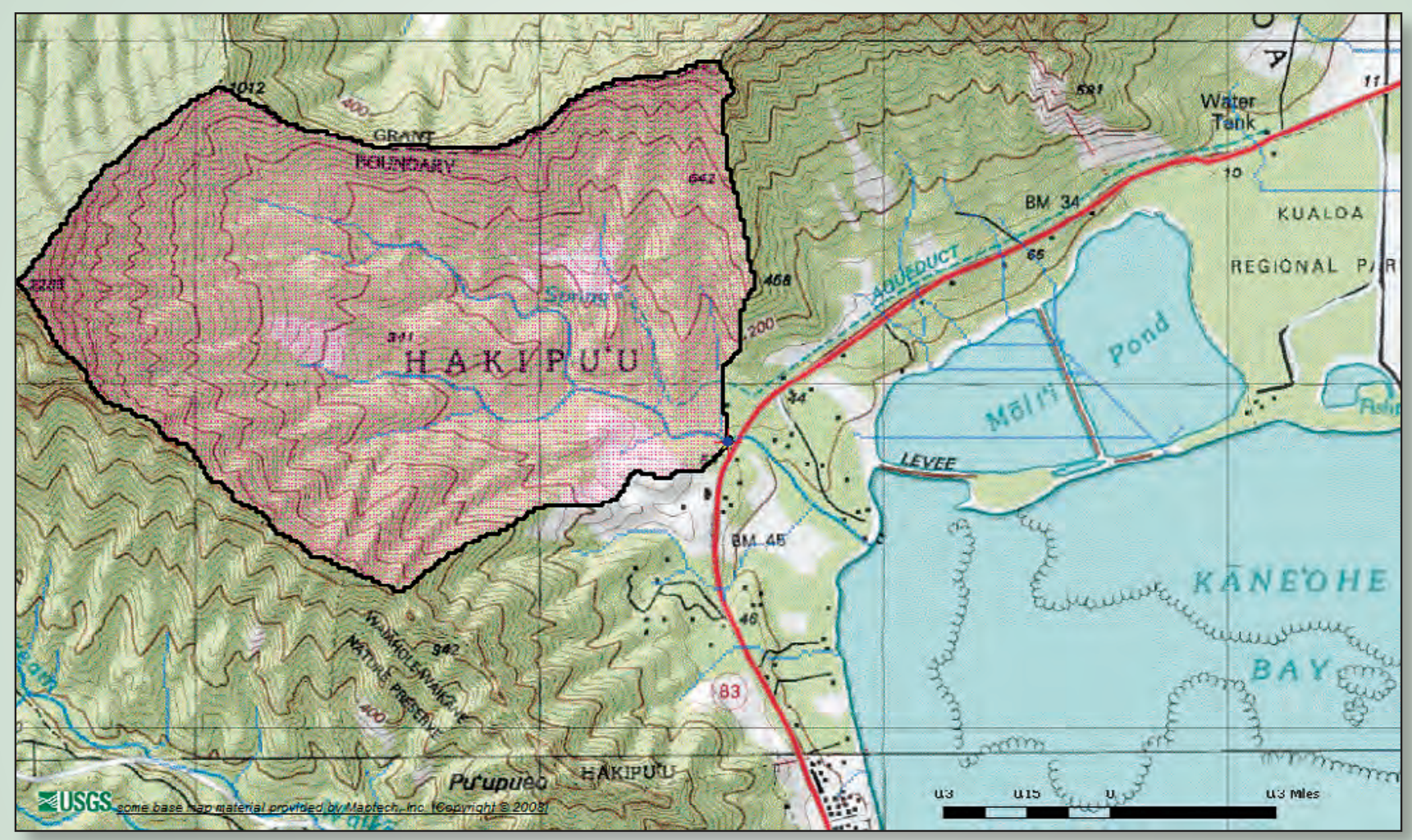

Data Series 680 
Cover: Screenshot of the Hawaii StreamStats web application, showing a delineated watershed. 


\section{Geospatial Datasets for Watershed Delineation and Characterization Used in the Hawaii StreamStats Web Application}

By Alan Rea and Kenneth D. Skinnerr

Prepared in cooperation with the State of Hawaii Department of Transportation

Data Series 680 


\title{
U.S. Department of the Interior \\ KEN SALAZAR, Secretary \\ U.S. Geological Survey \\ Marcia K. McNutt, Director
}

\author{
U.S. Geological Survey, Reston, Virginia: 2012
}

For more information on the USGS - the Federal source for science about the Earth, its natural and living resources, natural hazards, and the environment, visit http://www.usgs.gov or call 1-888-ASK-USGS.

For an overview of USGS information products, including maps, imagery, and publications, visit http://www.usgs.gov/pubprod

To order this and other USGS information products, visit http://store.usgs.gov

Any use of trade, product, or firm names is for descriptive purposes only and does not imply endorsement by the U.S. Government.

Although this report is in the public domain, permission must be secured from the individual copyright owners to reproduce any copyrighted materials contained within this report.

Suggested citation:

Rea, Alan, and Skinner, K.D., 2012, Geopatial datasets for watershed delineation and characterization used in the Hawaii StreamStats web application: U.S. Geological Survey Data Series 680, 12 p. 


\section{Contents}

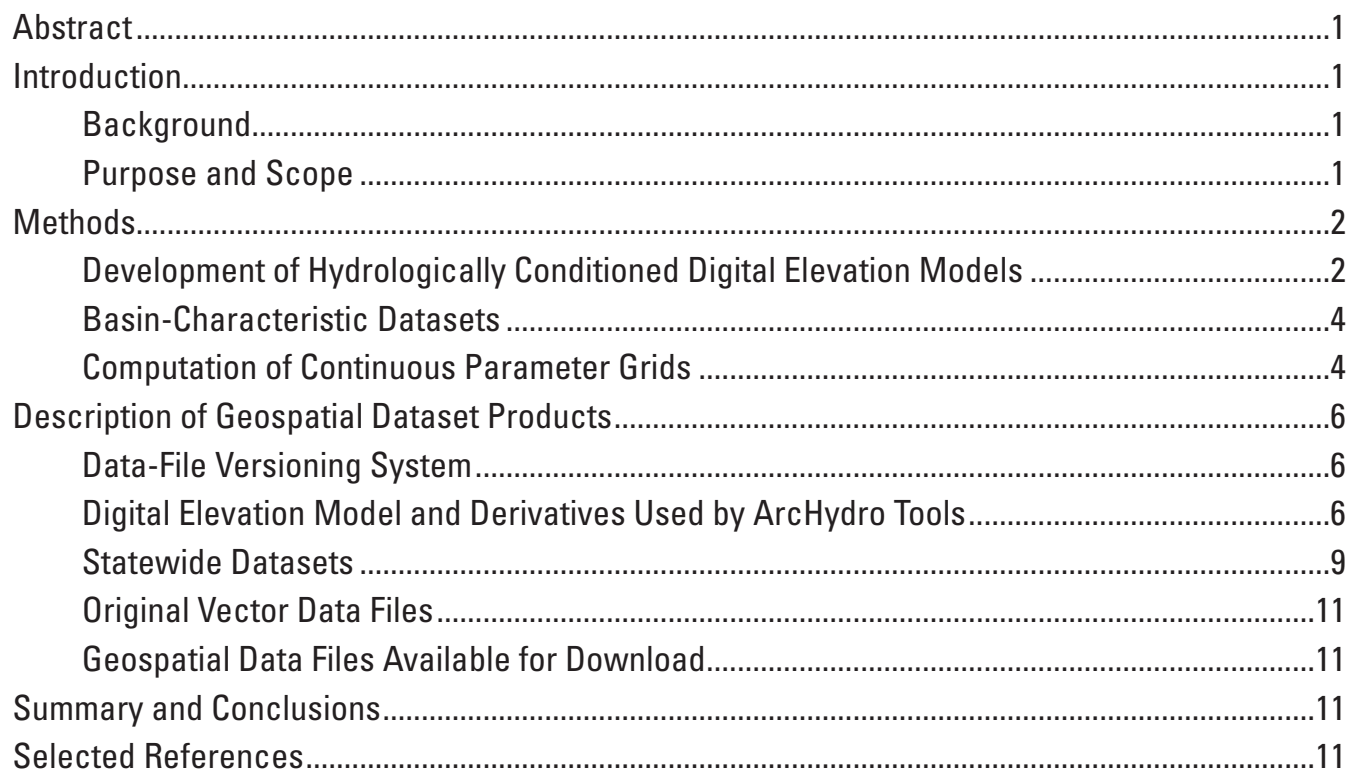

\section{Figures}

Figure 1. Maps showing (A) Horizontal displacement between NHD flowline and NED-derived stream, (B) NHD flowline catchments generated from NED-derived flow directions, and (C) NHD flowline catchments generated from HydroDEM (Modified from Johnston and others, 2009.) ................................. 3

Figure 2. Schematic diagram of AGREE process in a Digital Elevation Model cross section

Figure 3. Screen capture showing shaded-relief view of HydroDEM surface with burning of NHD streams and coastlines along the coastline of Kauai

\section{Tables}

Table 1. Example instructions for updating data components from geospatial datasets $\ldots$ 6

Table 2. ArcHydro datasets tiled by 8-digit hydrologic unit code (HUC) ................. 7

Table 3. Selected ArcHydro data elements stored in the global.mdb personal

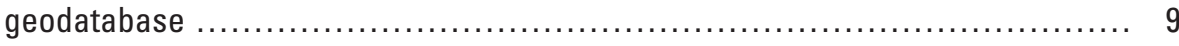

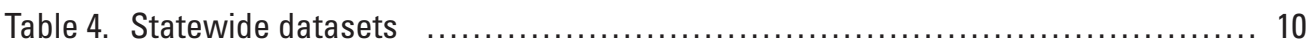




\section{Conversion Factors, Datums, and Abbreviations and Acronyms}

Conversion Factors

Inch/Pound to SI

\begin{tabular}{llll}
\hline & Multiply & \multicolumn{1}{c}{ By } & \multicolumn{1}{c}{ To obtain } \\
\hline inch (in.) & 2.54 & centimeter $(\mathrm{cm})$ \\
foot (ft) & 0.3048 & meter $(\mathrm{m})$ \\
\hline
\end{tabular}

Datums

Vertical coordinate information is referenced to the North American Vertical Datum of 1988 (NAVD 88).

Horizontal coordinate information is referenced to the North American Datum of 1983 (NAD 83).

Altitude, as used in this report, refers to distance above the vertical datum.

Abbreviations and Acronyms

DEM Digital Elevation Model

EDNA Elevation Derivatives for National Applications

ESRI Environmental Systems Research Institute, Inc.

FGDC Federal Geographic Data Committee

HUC hydrologic unit code

NED National Elevation Dataset

NHD National Hydrography Dataset

NHD Hi-Res National Hydrography Dataset High Resolution

NHD Plus National Hydrography Dataset Plus

USGS U.S. Geological Survey

UTM universal transverse mercator

WBD Watershed Boundary Dataset

XML Extensible Markup Language 


\title{
Geospatial Datasets for Watershed Delineation and Characterization Used in the Hawaii StreamStats Web Application
}

\author{
By Alan Rea and Kenneth D. Skinner
}

\begin{abstract}
The U.S. Geological Survey Hawaii StreamStats application uses an integrated suite of raster and vector geospatial datasets to delineate and characterize watersheds. The geospatial datasets used to delineate and characterize watersheds on the StreamStats website, and the methods used to develop the datasets are described in this report. The datasets for Hawaii were derived primarily from 10 meter resolution National Elevation Dataset (NED) elevation models, and the National Hydrography Dataset (NHD), using a set of procedures designed to enforce the drainage pattern from the NHD into the NED, resulting in an integrated suite of elevation-derived datasets. Additional sources of data used for computing basin characteristics include precipitation, land cover, soil permeability, and elevation-derivative datasets. The report also includes links for metadata and downloads of the geospatial datasets.
\end{abstract}

\section{Introduction}

The Hawaii application on the U.S. Geological Survey (USGS) StreamStats website uses several geospatial datasets to delineate and characterize watersheds. The geospatial datasets and methods used to develop them are described in this report.

\section{Background}

The StreamStats web application is based on an integrated suite of raster and vector geospatial datasets. Several functions, including the primary functions of watershed delineation and the computation of basin characteristics, involve spatial analyses combining raster and vector procedures in specific, carefully defined ways, based on use of the ESRI ArcHydro Tools [Environmental Systems Research Institute (ESRI), Inc., 2007]. Proper functioning of the StreamStats application requires that the geospatial datasets be processed to spatially integrate the raster and vector representations of the terrain and stream network. The raster and vector data models represent real-world features in fundamentally different ways; therefore, different representations of geographic features, such as the stream network, do not match exactly. The procedures used, however, modify both types of data to minimize differences and to maximize the agreement between the raster and vector representations of the terrain and stream network.

\section{Purpose and Scope}

This report describes the datasets and procedures used to create an integrated suite of geospatial datasets derived from 10-m resolution Digital Elevation Models (DEMs) and the 1:24,000-scale National Hydrography Dataset (NHD), plus several datasets used to compute basin characteristics. These datasets form the geospatial basis of the Hawaii StreamStats application. (More information about StreamStats is available at http://streamstats.usgs.gov/; U.S. Geological Survey, 2008). This report provides links to Federal Geographic Data Committee (FGDC)-compliant metadata (Federal Geographic Data Committee, 1998) that describe these geospatial datasets, and to distribution information that describes how to obtain the datasets.

The StreamStats web application includes several other components, such as a database of measured streamflow statistics, a process to estimate streamflow statistics at ungaged locations using regional regression equations (Oki and others, 2010), and functions based on upstream or downstream network traces using the stream network. This report is limited to describing the geospatial datasets related to watershed delineation and the computation of basin characteristics, and the procedures used to develop these geospatial datasets. 


\section{Methods}

\section{Development of Hydrologically Conditioned Digital Elevation Models}

The datasets used in this project were derived primarily from the 10-m resolution DEMs produced by the USGS, and the 1:24,000-scale NHD High Resolution (NHD Hi-Res). Previous experience with 30-m resolution DEM data processed with standard methods [see Elevation Derivatives for National Applications (EDNA) http://edna. usgs.gov; U.S. Geological Survey, 2005] identified many shortcomings that were avoided in the development of these datasets. Moore and others (2004) described a process used to produce a hydrologically conditioned DEM, referred to in this report as the "HydroDEM." The HydroDEM process was further refined during development of datasets for the Idaho StreamStats application (Rea and Skinner, 2009) and subsequently was used to develop data for many other USGS StreamStats websites. The process also became the basis for the elevation-derived components of the National Hydrography Dataset Plus (NHDPlus). More information on the NHDPlus is available at http://www.horizon-systems.com/ nhdplus/ (Horizon Systems Corporation, 2006).

The source DEM was obtained in September 2006 from the $1 / 3$ arc second resolution National Elevation Dataset (NED) and was projected into the Universal Transverse Mercator (UTM) projection, Zone 4, and based on the North American Datum of 1983 for each of the five largest islands of the State of Hawaii. Because the DEM and derived gridded datasets are large, the data were divided into tiles based on the 8-digit Hydrologic Unit Codes (HUC), also known as "subbasins," of the National Watershed Boundary Dataset (WBD) (Natural Resources Conservation Service, 2008). For Hawaii, the subbasins correspond to the major islands. The five largest islands included in this project were: Hawaii (HUC 20010000), Maui (HUC 20020000), Molokai (HUC 20050000), Oahu (HUC 20060000), and Kauai (HUC 20070000). The coastlines from the NHD were used to define the outlines of the islands. A 1,000-m-wide buffer area was included around each island. The HydroDEMs were processed to set all grid cells inside the islands to a minimum elevation of $+1 \mathrm{~cm}$, and the cells within the buffer area outside each island were set to $-600 \mathrm{~cm}$. This ensured that flow directions derived from the HydroDEM would indicate flow from the island, across the coastline, and into the ocean. Note the HydroDEM is used only to derive flow direction, and is not used to compute any elevation-dependent basin characteristics.

The NHD vector streams (downloaded in May 2005) were integrated into the raster HydroDEM data using a process often referred to as "stream burning" (Saunders, 2000). These modifications were needed because the drainage path defined by the original NED surface often does not closely match the 1:24,000-scale NHD streams. The stream locations in the NHD, coming from the topographic maps, ultimately were derived from aerial photograph interpretation and field verification. The drainage path derived from the NED surface, however, is sensitive to blockages at culverts and dams, and under-sampling of narrow channels in the rasterization process. In addition, the NED surface often does not retain enough detail to represent stream channels accurately in areas of low relief. Figure $1 A$ illustrates a common example of the differences in the horizontal positions of NHD streams and NED-derived streams. Where this offset distance is greater than one grid-cell width, some cells may not be identified as being upslope from the NHD stream segment; therefore, cells would be erroneously excluded from watersheds or catchments (the area draining to a particular stream reach) delineated using these data (fig. 1B). For these reasons, the stream-burning process was used to give the NHD streams preference over the NED-derived streams. Figure $1 C$ shows that the stream-burning process corrects for DEM flow path displacement errors.

The stream-burning process uses computer algorithms in an Arc Macro Language (AML) program called AGREE, developed by Hellweger and Maidment (1997). Figure 2 shows that AGREE "burns" a "canyon" into the NED-based DEM by subtracting a specified vertical distance from the elevation cells beneath the NHD vector streamlines. The vertical exaggeration of the canyon is controlled by specifying a "Sharp Drop Distance." A negative "sharp" drop distance $(-500 \mathrm{~m})$ was used.

AGREE also "smooths" the elevation adjacent to NHD stream cell locations in the HydroDEM within a buffer distance specified by the AGREE program user. Typically, the buffer distance used is related to a common horizontal displacement error between NHD and NED-derived streams; this distance is seldom exceeded. For this project, the buffer distance was set to $60 \mathrm{~m}$ on each side of the NHD flowline. The smoothing process changes the original DEM grid-cell elevations within the buffer area to create a downward sloping gradient towards the canyon created beneath the NHD streams. The steepness of the slope within the buffer is controlled by the AGREE "Smooth Drop/Raise Distance" option. A smooth drop distance of $-5 \mathrm{~m}$ was specified for this project. Figure 2 illustrates how AGREE changes the original DEM surface using all the specified parameters of AGREE.

The use of AGREE's $60 \mathrm{~m}$ smooth drop buffer distance of the NHD streams potentially may cause problems at headwater flowlines that begin at or near drainage divides. The $60 \mathrm{~m}$ buffer distance at these headwater streams may extend across the drainage divides and into the adjacent basin area, thereby including areas outside the true catchment area. Input datasets were spot-checked to ensure this situation did not exist, and if it did, the NHD streams were trimmed back from the divides. 
A. Horizontal displacement between NHD flowline and NED-derived stream

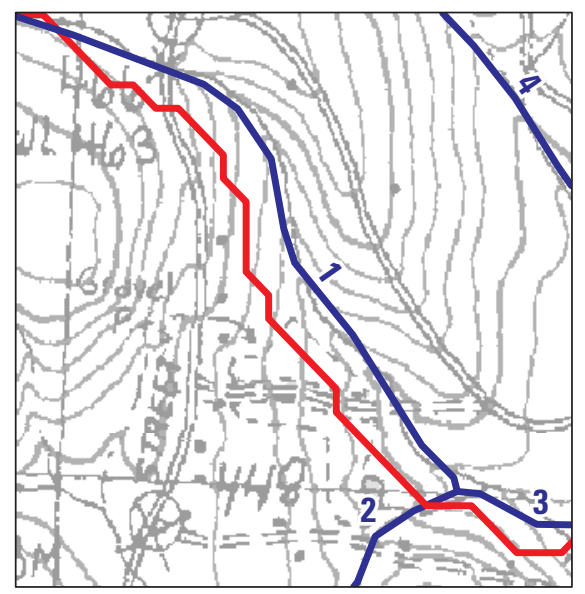

Base from U.S. Geological Survey Digital Raster Graphic, Stoddard, N.H., 1:25,000, 1984
B. NHD flowline catchments generated from NED-derived flow directions

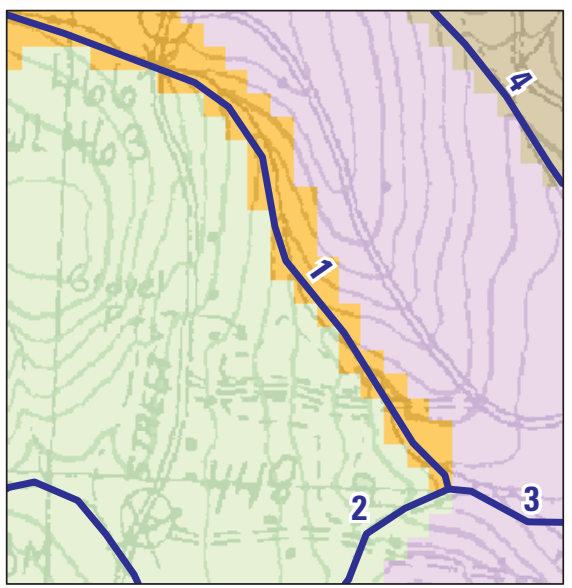

EXPLANATION
C. NHD flowline catchments generated from HydroDEM

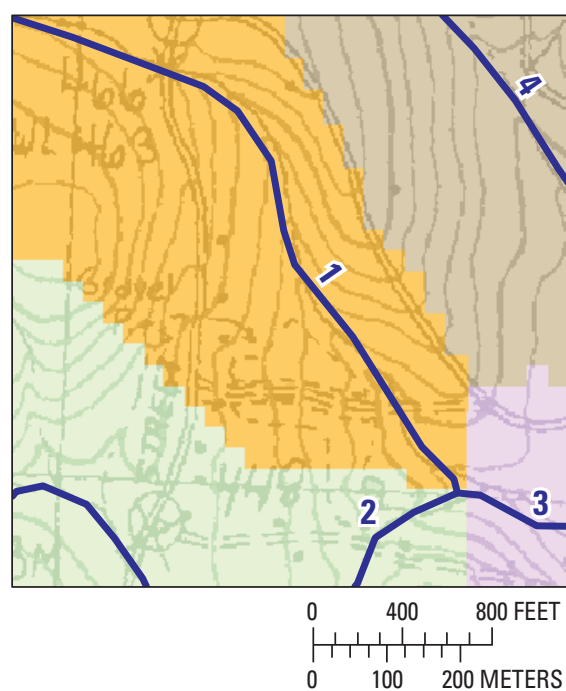

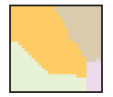

National Hydrography Dataset (NHD) flowline catchments

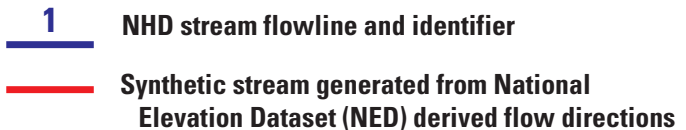

Figure 1. (A) Horizontal displacement between NHD flowline and NED-derived stream, $(B)$ NHD flowline catchments generated from NED-derived flow directions, and (C) NHD flowline catchments generated from HydroDEM. (Modified from Johnston and others, 2009.)

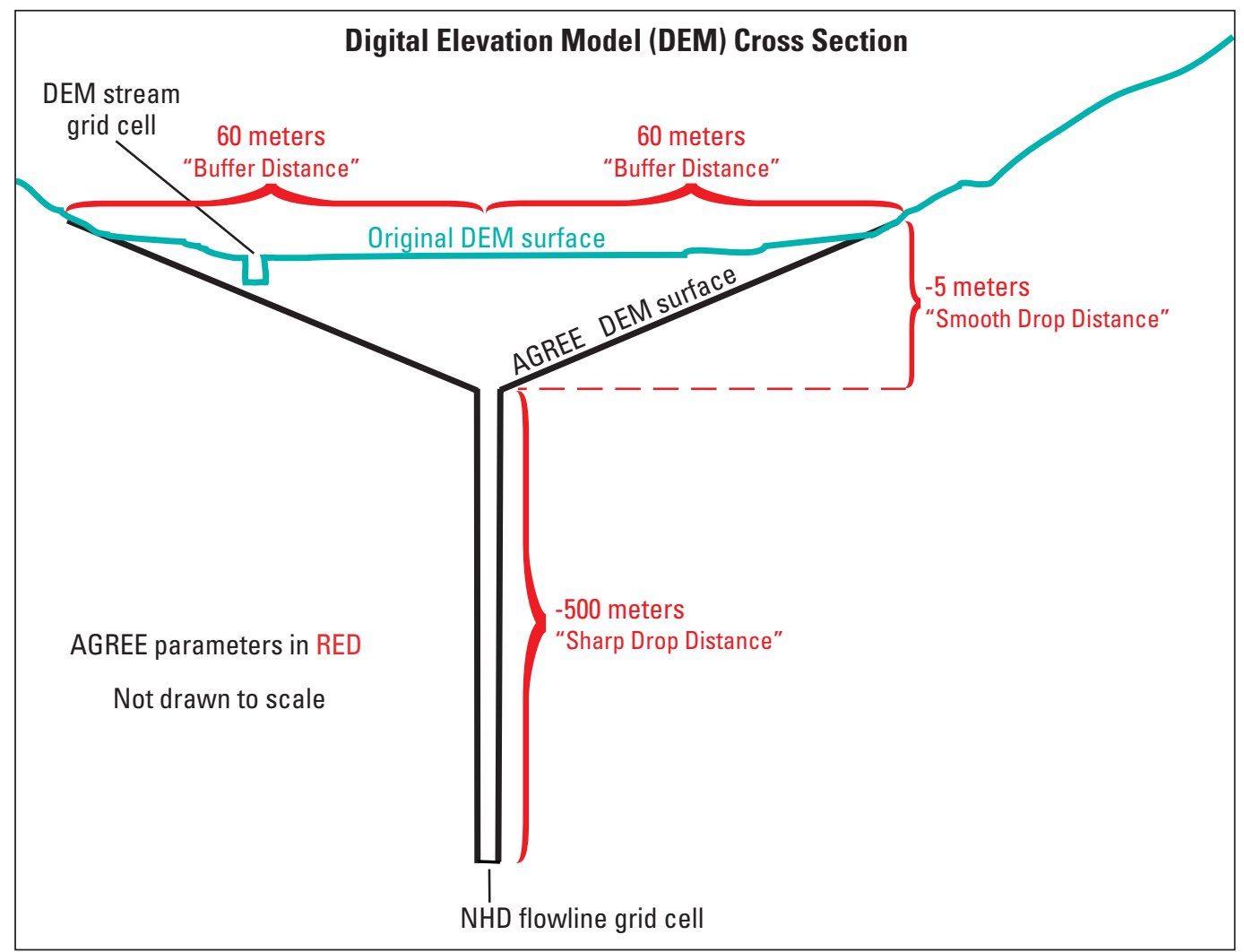

Figure 2. Schematic diagram of AGREE process in a Digital Elevation Model cross section. 
Many StreamStats projects use the WBD boundaries as "walls" in the HydroDEM. The advantage of doing so is that StreamStats watershed delineations will then agree well with the WBD boundaries. Work was begun on this project in 2006, and at the time the WBD had not been finalized for Hawaii. Numerous discrepancies were observed between watersheds that had been delineated for USGS stream gages and the WBD boundaries, thus, WBD boundaries were not included in the process. Reviews of early results identified several delineated watersheds that conflicted with previously delineated watersheds for USGS stream gages. To remedy those conflicts, short lines were digitized to serve as "walls" in the HydroDEM. The process raised DEM cells along those lines, preventing flow across those lines. Walls were used only for the islands of Hawaii and Maui.

The process was further refined by imposing a "bathymetric gradient" within wide rivers and lakes or ponds. The bathymetric gradient ensured that the surface sloped toward the artificial-path flowlines of the NHD, which generally follow the centerlines of these NHD water-body features. The gradient was applied prior to running AGREE. The bathymetric gradient process applied algorithms similar to those used in AGREE to create a gently sloping gradient from water-body shorelines toward the artificial path flow lines. The result of this process was that flow routed across these areas, which were perfectly flat in the original DEM, closely matched the pattern of the artificial-path flowlines. The resulting synthetic drainage pattern matched the NHD drainage network much more closely than the parallel synthetic drainage lines that often are produced from standard DEMs. This greatly improves the usability of the surface for watershed and catchment delineations. Rea and Skinner (2009, figs. 5A and 5B) show the improvement resulting from the bathymetric gradient process. Because there are few large waterbodies or wide streams in Hawaii, this process did not influence the results in very many places.

The last step in the process creates a "filled" DEM surface grid with the ARC/INFO GRID (Environmental Systems Research Institute, Inc., 2011) command "FILL," which removes depressions. This step ensured all elevation cells in the basin had a defined drainage direction. A flow direction grid then was produced from the filled DEM surface. This flow-direction grid was the foundation for developing a flow-accumulation grid and other hydrologic derivatives, using the techniques described by Jenson and Domingue (1988).

Figure 3 illustrates how the HydroDEM was developed in a coastal area. Figure 3 shows the shaded relief and synthetic drainage network (dark blue pixels) derived from the $10-\mathrm{m}$ HydroDEM specially processed for this project. The effect of lowering the ocean in the buffer area can be seen. Some of the streams shown on the map stopped before reaching the coast. The dark blue pixels show the synthetic drainage network continuing on to the coastline.

\section{Basin-Characteristic Datasets}

Numerous datasets prepared for overlay on the delineated watershed within the StreamStats application are known as basin-characteristic datasets. The basin-characteristic datasets provided for Hawaii include precipitation, land cover, soil permeability, and elevation-derivative datasets. Twenty-eight precipitation-frequency datasets from Perica and others (2009) are provided. These were projected to UTM, sampled at 450-m resolution, and expanded by two grid cells to completely cover the islands. A mean annual precipitation grid was developed using the isohyets from Giambelluca and others (1986). The isohyets were converted to a $150-\mathrm{m}$ resolution grid using the Topo to Raster tool in ArcGIS (Environmental Systems Research Institute, Inc., 2011). The soil permeability datasets came from the Soil Survey Geographic (SSURGO) Database (U.S. Department of Agriculture, 2003). Grids containing 1 (true) and 0 (false) for each grid cell were developed from several categories of the 2001 National Land Cover Dataset (NLCD; U.S. Environmental Protection Agency, 2001; Homer and others, 2004). Additional basin-characteristic grids, such as slope, were derived from the NED elevation grids. The individual datasets are further described in tables 2 and $\underline{4}$.

\section{Computation of Continuous Parameter Grids}

Verdin and Worstell (2008) describe a method using a weighted flow accumulation function to compute continuous parameter grids. In this discussion, a grid in which each cell contains the value of some parameter, measured for the entire drainage area upstream of that cell, is referred to as a continuous parameter grid. The flow-accumulation grid described by Jenson and Domingue (1988) is the most basic continuous parameter grid. Each cell in a flow-accumulation grid contains the number of cells upstream of that cell. The upstream drainage area may be determined by multiplying the number of cells by the area of a cell. This area should be adjusted by adding the area of the cell of interest, because the flow accumulation grid does not include this cell.

The ARC/INFO GRID flow accumulation function (Environmental Systems Research Institute, Inc., 2011) allows the use of an optional "weight" grid. When using a weight grid, the flow accumulation function sums values from the weight grid for each cell as it accumulates values downstream. Using a precipitation grid for a weight grid, for example, the weighted flow accumulation function sums the precipitation depths from all upstream cells, producing a grid that represents - with appropriate unit conversions - the total volume of precipitation in the watershed upstream of each cell. In contrast, if no weight grid is given, the flow accumulation function simply totals the number of upstream cells, a process called "unweighted flow accumulation" in this report. The weighted flow accumulation value, divided by the unweighted flow accumulation value, gives the average of the weight grid 


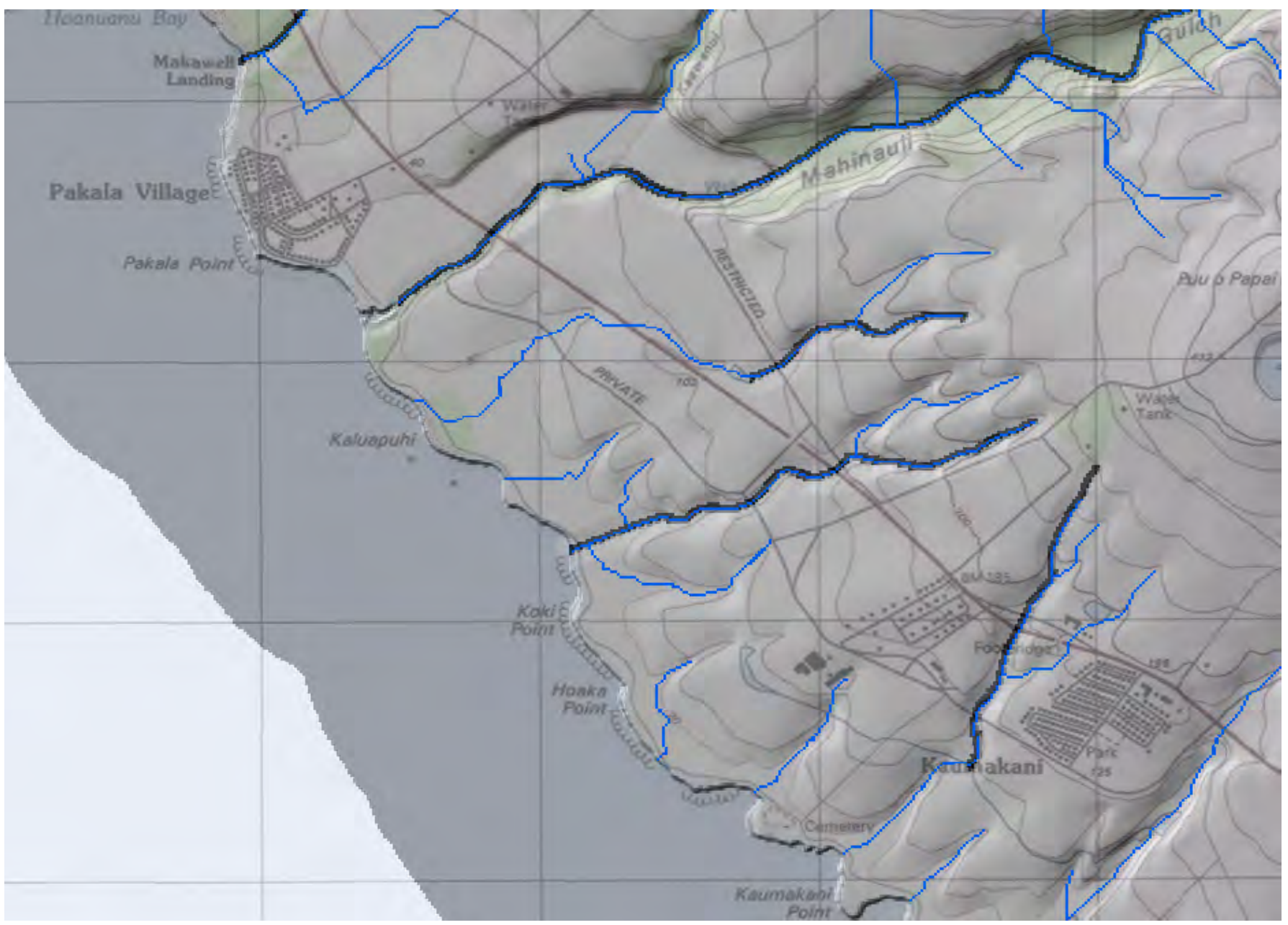

Figure 3. Shaded-relief view of HydroDEM surface with burning of NHD streams and coastlines along the coastline of Kauai.

upstream of any grid cell of interest. Adjusting to include the cell of interest, the formula given in equation 1 may be used to compute the mean value of a weight grid for the watershed above and including the cell:

where

$$
P_{i}=\left(f a c W p_{i}+p_{i}\right) /\left(f a c_{i}+1\right),
$$

$P_{i}$ is the average value of parameter $P$ in the watershed of cell $i$.

$f a c W p_{i}$ is the weighted flow accumulation at cell $i$,

$p_{i}$ is the value of the parameter grid $P$ at cell $i$, and

$f a c_{i}$ is the value of the unweighted flow accumulation at cell $i$.

Equation 1 may be used with continuous-value parameters, such as elevation or precipitation, which may be expressed as a grid of real values. Equation 1 also may be used with single-value categorical grids. For example, using a grid containing 1 for every cell categorized as forested in a land-cover dataset, and 0 for every other cell, equation 1 may be used to compute the fraction of the watershed area for grid cell $i$ that is forested.

The basic assumption of equation 1 is that the quantity of interest may be determined by an area-weighted average of the upstream cell values in the weight grid. Therefore, equation 1 may not be used with maximum, minimum, or range type parameters, or parameters that depend on the geometric shape of the entire watershed or stream channel.

The continuous parameter grids were evaluated for 235 streamgage sites and results were compared to the original parameter values. Most agreed very well, however, a few individual values differed by more than 1 percent. These differences appear to be due to accumulation of rounding errors as values are accumulated downstream. 


\section{Description of Geospatial Dataset Products}

A suite of geospatial datasets for the State of Hawaii has been compiled to support the Hawaii StreamStats web application. Links are provided for metadata for the datasets. The metadata include distribution information on obtaining these datasets for use outside the Hawaii StreamStats web application.

\section{Data-File Versioning System}

In a collection as large as these geospatial datasets, errors may be detected and the data may need to be updated. Therefore, the data are distributed using a versioning system. Each compressed download file (with a ".zip" extension) contains the version information in the filename in the form of "Vnn," where "nn" is the data version number. In this manner, each data component may be versioned and distributed independently. The data is distributed in ".zip" files, one per 8-digit HUC, plus one ".zip" file for the ArcHydro Global dataset, and one for the statewide layers. For example, the file "ds680_20020000_V01.zip" would contain the entire folder for HUC 20020000 (Maui). A file named "ds680_20020000_ V02.zip" would indicate that data have been updated, and that version 02 data should be used. If a change to one dataset results in the need to change others, all affected datasets will be updated, and the data distribution site will be maintained so it includes a complete set of compatible dataset versions.

Each ".zip" file includes a text file that indicates the version of the accompanying data component. For example, the "ds680_20020000_V02.zip" file would contain a file named "ds680_20020000_V02.txt," which will extract into the archydro $\backslash 20020000$ folder. The name of this file will indicate the version of the data in the folder. The file itself contains an explanation of the versioning system, and a summary of edits made since the first version of the dataset was released.

When the ".zip" files are uncompressed, each file should be extracted to the same location. This ensures that all data files and version files are extracted to the appropriate locations relative to each other. If a new version of a data component is available, the previous component should first be deleted in its entirety before the new version is extracted. The examples in table 1 show how to remove each type of data component. In the examples, all original data components are assumed to have been extracted to the D:\data\hi_ss $\backslash$ folder.
Table 1. Example instructions for updating data components from geospatial datasets.

[Huc\# is the 8-digit hydrologic unit code. D:\data \hi_ss $\backslash$ is the disk location to which .zip file archives were extracted]

\begin{tabular}{|c|c|}
\hline Component & $\begin{array}{l}\text { Delete prior to extracting } \\
\text { new version of .zip file }\end{array}$ \\
\hline ArcHydroGlobal & $\mathrm{D}: \backslash$ data $\backslash$ hi_ss $\backslash$ archydro $\backslash$ global.mdb \\
\hline StatewideLayers & D:\data $\backslash$ hi_ss $\backslash$ statewide $\backslash$ (delete entire folder) \\
\hline Huc\# & D: \data \hi_ss $\backslash$ archydro\Huc\# (delete entire folder) \\
\hline
\end{tabular}

\section{Digital Elevation Model and Derivatives Used by ArcHydro Tools}

Hawaii StreamStats uses the ArcHydro Tools, developed by ESRI and enhanced under contract by ESRI for StreamStats. The ArcHydro Tools are available as a free download at http://support.esri.com/en/downloads/datamodel/ detail/15 (Environmental Systems Research Institute, Inc., 2007). The tools include documentation and a tutorial.

The Hawaii ArcHydro datasets are organized and tiled by 8 -digit HUC. These units also are known as subbasins in the WBD nomenclature, and in Hawaii correspond to the major islands. The actual island shorelines came from the NHD, however, so these datasets should not be used as a substitute for WBD. The data structure within each HUC tile is identical, and consists of an ESRI personal geodatabase named for the HUC and several ESRI Grid-format datasets. The dataset structure for each HUC is listed in table 2; note the units in the precipitation grid datasets are thousandths of an inch. This is so the grids may be more efficiently stored as integer data without losing precision. The basin characteristics computed in the ArcHydro Tools are computed from these grids, but reported in decimal inches.

A "global" database also is available for Hawaii in the file "global.mdb." This database ordinarily contains the information needed to link the HUCs together to delineate watersheds that span more than one HUC. Because there is no overland flow between islands, many of the datasets in this database serve no functional role in Hawaii; however, the data structure must be present for the software to work properly. Selected data elements of the ArcHydro global geodatabase are shown in table 3. 
Table 2. Archydro datasets tiled by 8-digit hydrologic unit code (HUC).

[Abbreviations NED, National Elevation Dataset; UTM, universal transverse mercator; NAD 83, North American Datum of 1983; NGVD 88, North American Vertical Datum of 1988; DEM, digital elevation model; NHD, National Hydrography Dataset; NLCD, National Land Cover Database; NRCS SSURGO, National Resources Conservation Service Soil Survey Geographic Database; m, meter]

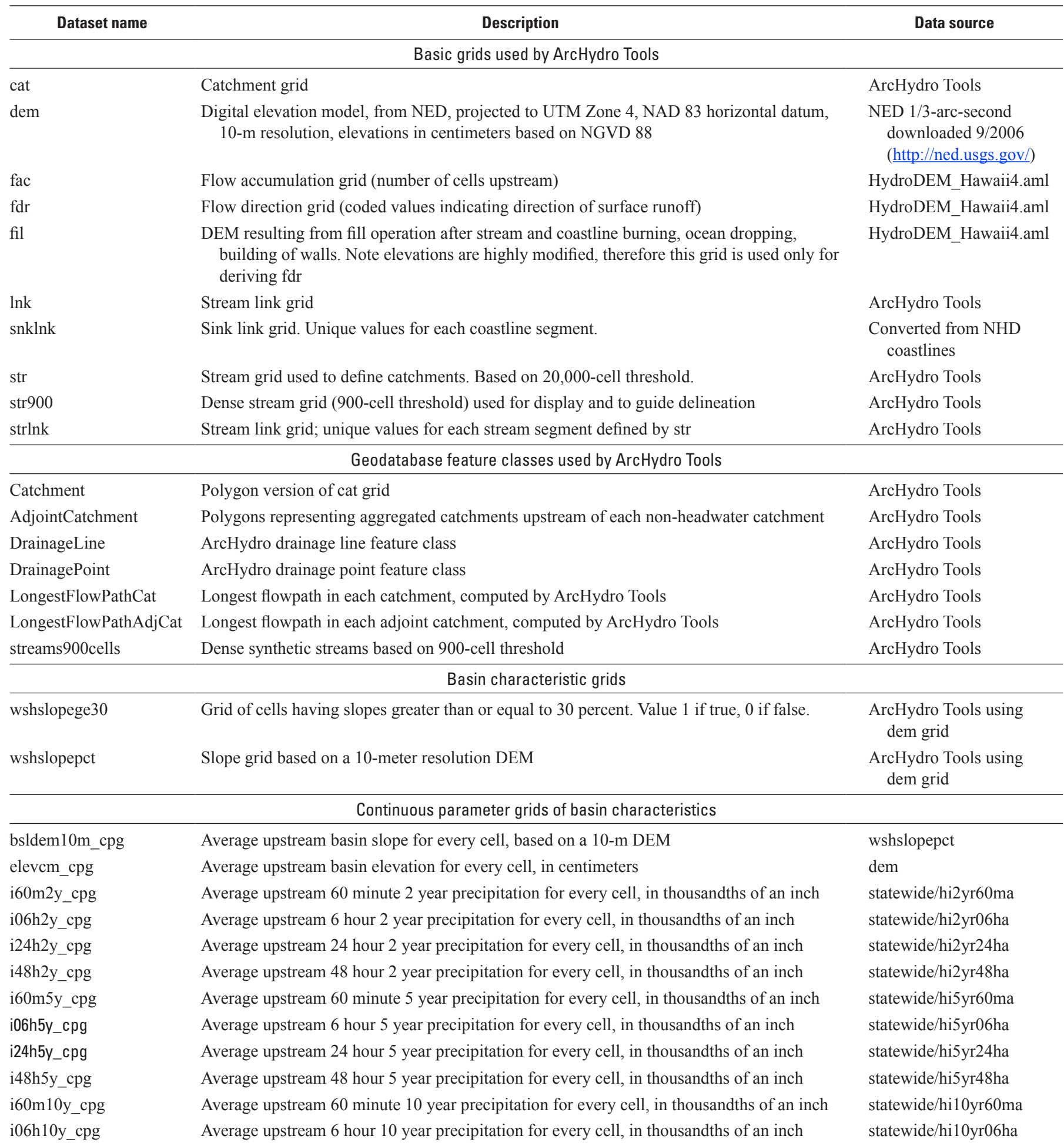


Table 2. ArcHydro datasets tiled by 8-digit Hydrologic unit code (HUC).-Continued

[Abbreviations NED, National Elevation Dataset; UTM, universal transverse mercator; NAD 83, North American Datum of 1983; NGVD 88, North American Vertical Datum of 1988; DEM, digital elevation model; NHD, National Hydrography Dataset; NLCD, National Land Cover Database; NRCS SSURGO, National Resources Conservation Service Soil Survey Geographic Database; m, meter]

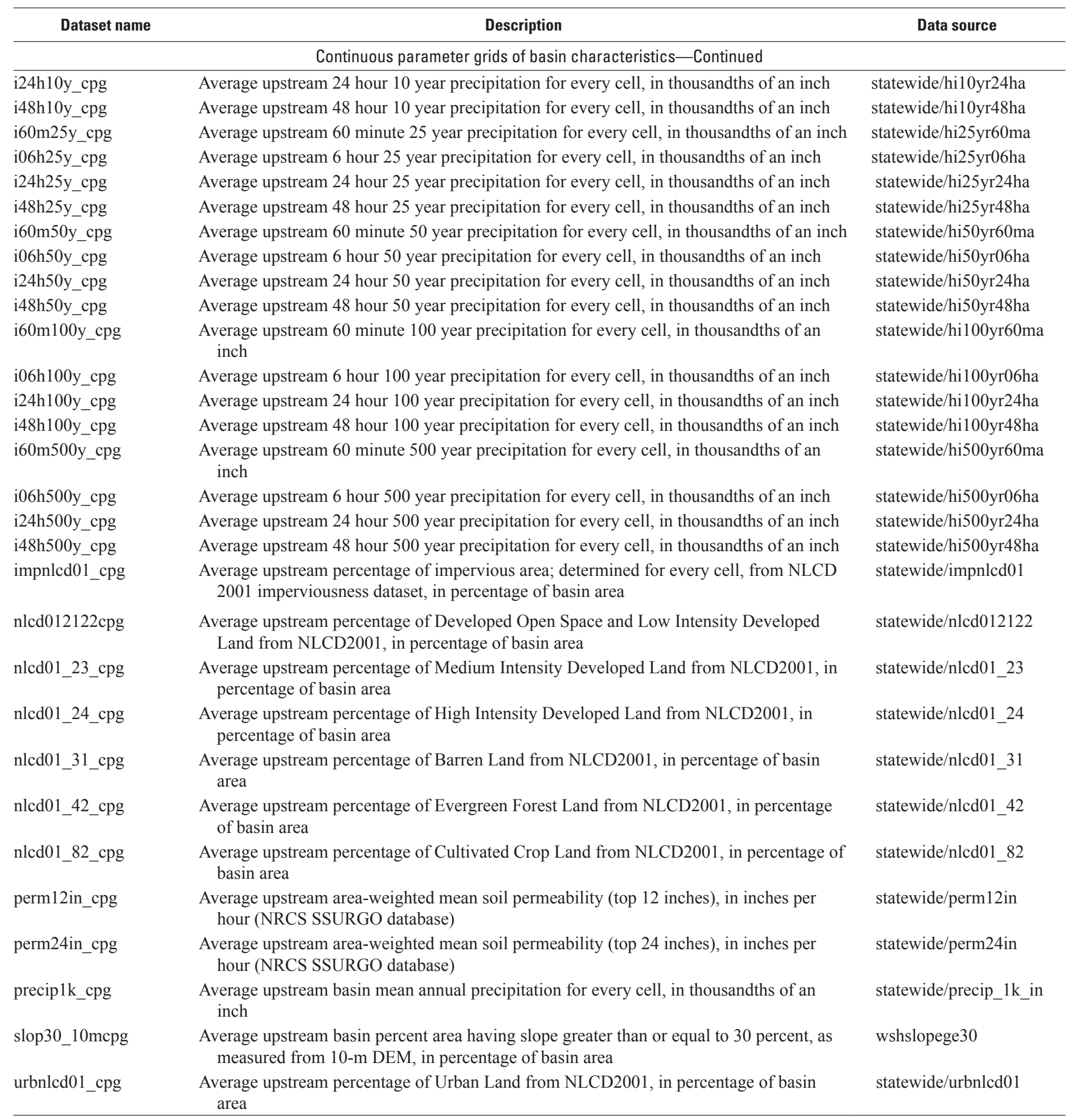


Table 3. Selected ArcHydro data elements stored in the global.mdb personal geodatabase.

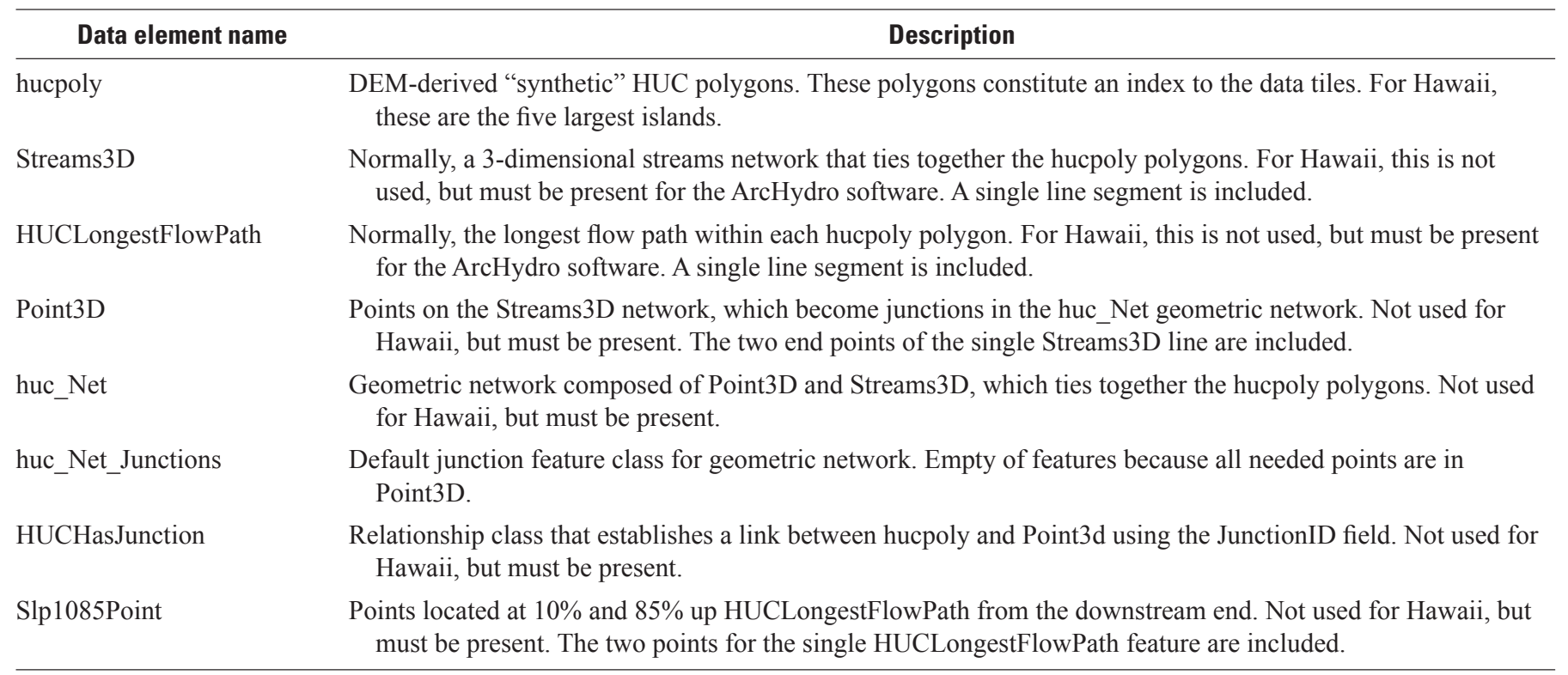

To use these data with the ArcHydro Tools, users need to download the ds680_ArcHydroGlobal.zip and ds680_ StatewideLayers.zip files, plus any 8-digit HUC datasets that include their area of interest. The 8-digit HUC datasets needed may be determined by overlaying the user's area of interest with the "hucpoly" polygon feature class in the global geodatabase contained in the ds680_ArcHydroGlobal.zip file. A new folder should be created and all ".zip" files should be extracted into this folder. This procedure will ensure that the datasets are in their proper locations relative to one another.

A fresh ArcMap document (identified by the ".mxd" file extension) is created by starting ArcMap, loading the "Layers" feature dataset (including all component feature classes) from the global.mdb file, and saving the document with a new file name. The ArcHydro Tools use configuration information stored in Extensible Markup Language (XML) to define basin characteristics and other configuration options.

XML code for the Hawaii StreamStats configuration has been incorporated into versions of the ArcHydro Tools released after February 16, 2012. The ArcHydro Tools "Configure Function Parameters" tool may be used to load the configuration for StreamStats, using either the configuration named "Hawaii," or the configuration named "Hawaii_CPGs." This will load an XML configuration designed to work with these data. The "Hawaii" configuration may be used for computing basin characteristics for any watershed polygon, even ones not delineated using one of the flow-direction grids included with these datasets. The "Hawaii_CPG's" configuration may only be used with watershed polygons delineated using one of the flow-direction grids included with these datasets, but this configuration uses faster computation methods than the "Hawaii" configuration. The "Local Point Delineation" or "Global Point Delineation" tools from the ArcHydro Tools may be used to delineate watersheds. The "Compute Local Parameters" or "Compute Global Parameters" menu options then may be used to compute watershed characteristics. For further explanation of the functions of the above datasets, and for instructions on using the tools, see the ArcHydro Tools documentation, available on the ArcHydro Tools download site.

\section{Statewide Datasets}

A separate folder named "statewide" is created by extracting the ds680_StatewideLayers.zip file, and contains a personal geodatabase containing exclusion polygons, a grid of the peak-flow regression regions (Oki and others, 2010), and grids used to compute basin characteristics. The peak flows regression regions grid is named "hi_pkreg." This grid represents the regions shown in Oki and others (2010, figs. 2-6.) The basin-characteristic grids should be used to compute basin characteristics for watershed datasets edited by the user after the automated delineation process. (Continuous parameter grids in each HUC folder are available for unedited watershed datasets.) Note the units in the precipitation grid datasets are thousandths of an inch. This is so the grids may be more efficiently stored as integer data without losing precision. The basin characteristics computed in the ArcHydro Tools are computed from these grids, but reported in decimal inches.

The exclusion polygons in the ExcludePolys.mdb geodatabase are areas for which delineation is restricted in StreamStats, or for which additional information is provided. For Hawaii, the one exclusion area identifies an irrigated area in western Kauai where delineated watersheds may be inaccurate. 
Table 4. Statewide datasets.

\begin{tabular}{|c|c|c|}
\hline Dataset name & Description & Data source \\
\hline \multicolumn{3}{|c|}{ Basin characteristic grids } \\
\hline hi2yr60ma & 60 Minute 2 Year Precipitation, in thousandths of an inch & Perica and others (2009) \\
\hline hi2yr24ha & 24 Hour 2 Year Precipitation, in thousandths of an inch & Perica and others (2009) \\
\hline hi2yr48ha & 48 Hour 2 Year Precipitation, in thousandths of an inch & Perica and others (2009) \\
\hline hi5yr24ha & 24 Hour 5 Year Precipitation, in thousandths of an inch & Perica and others (2009) \\
\hline hi5yr48ha & 48 Hour 5 Year Precipitation, in thousandths of an inch & Perica and others (2009) \\
\hline hi10yr60ma & 60 Minute 10 Year Precipitation, in thousandths of an inch & Perica and others (2009) \\
\hline hi10yr06ha & 6 Hour 10 Year Precipitation, in thousandths of an inch & Perica and others (2009) \\
\hline hi10yr24ha & 24 Hour 10 Year Precipitation, in thousandths of an inch & Perica and others (2009) \\
\hline hi25yr24ha & 24 Hour 25 Year Precipitation, in thousandths of an inch & Perica and others (2009) \\
\hline hi25yr48ha & 48 Hour 25 Year Precipitation, in thousandths of an inch & Perica and others (2009) \\
\hline hi50yr60ma & 60 Minute 50 Year Precipitation, in thousandths of an inch & Perica and others (2009) \\
\hline hi50yr06ha & 6 Hour 50 Year Precipitation, in thousandths of an inch & Perica and others (2009) \\
\hline hi50yr24ha & 24 Hour 50 Year Precipitation, in thousandths of an inch & Perica and others (2009) \\
\hline hi50yr48ha & 48 Hour 50 Year Precipitation, in thousandths of an inch & Perica and others (2009) \\
\hline hi100yr60ma & 60 Minute 100 Year Precipitation, in thousandths of an inch & Perica and others (2009) \\
\hline hi100yr06ha & 6 Hour 100 Year Precipitation, in thousandths of an inch & Perica and others (2009) \\
\hline hi100yr24ha & 24 Hour 100 Year Precipitation, in thousandths of an inch & Perica and others (2009) \\
\hline hi100yr48ha & 48 Hour 100 Year Precipitation, in thousandths of an inch & Perica and others (2009) \\
\hline nlcd01_23 & Medium Intensity Developed Land from NLCD2001, (1/0 grid) & Homer and others (2004) \\
\hline nlcd01_24 & High Intensity Developed Land from NLCD2001, (1/0 grid) & Homer and others (2004) \\
\hline nlcd01_31 & Barren Land from NLCD2001, (1/0 grid) & Homer and others (2004) \\
\hline nlcd01_42 & Evergreen Forest Land from NLCD2001, (1/0 grid) & Homer and others (2004) \\
\hline nlcd01_82 & Cultivated Crop Land from NLCD2001, (1/0 grid) & Homer and others (2004) \\
\hline perm12in & $\begin{array}{l}\text { Area-weighted mean soil permeability (top } 12 \text { inches), in inches per hour } \\
\text { (NRCS SSURGO database) }\end{array}$ & $\begin{array}{l}\text { SSURGO (U.S. Department of } \\
\text { Agriculture, 2003) }\end{array}$ \\
\hline perm24in & $\begin{array}{l}\text { Area-weighted mean soil permeability (top } 24 \text { inches), in inches per hour } \\
\text { (NRCS SSURGO database) }\end{array}$ & $\begin{array}{l}\text { SSURGO (U.S. Department of } \\
\text { Agriculture, 2003) }\end{array}$ \\
\hline precip_1k_in & Mean annual precipitation, in thousandths of an inch & Giambelluca and others (1986) \\
\hline urbnlcd01 & Urban Land from NLCD2001, (1/0 grid) & Homer and others (2004) \\
\hline \multicolumn{3}{|c|}{ Other datasets } \\
\hline hi_pkreg & Grid of peak-flow regression regions & Oki and others (2010) \\
\hline str900 & Grid of synthetic streams based on a 900-cell flow-accumulation threshold & fac grids for each island \\
\hline ExcludePolys & $\begin{array}{l}\text { Polygon providing informational warning regarding watershed delineations in an } \\
\text { irrigated area }\end{array}$ & digitized \\
\hline
\end{tabular}




\section{Original Vector Data Files}

A folder named "orig_data" is created by extracting the ds680_OriginalData.zip file, and contains a personal geodatabase containing the NHD, and shapefiles used in the HydroDEM process. These files are provided as a means to document exactly which lines were used to develop the HydroDEMs. Each folder contains a line shapefile named for the 8-digit HUC code, containing the NHD flowlines that comprise the coastline for that island. The "hydrolines.shp" shapefile contains the lines that were burned into the DEM. These lines were selected from the NHD flowlines, with some minor editing in places. The "wbpolys.shp" shapefile contains the water-body polygons that were selected from the NHD and used in the bathymetric gradient process. The folders for HUCs 20010000 (Hawaii) and 20020000 (Maui) also contain a "walls.shp" shapefile, which contains the lines that were superimposed on the surface as "walls."

\section{Geospatial Data Files Available for Download}

Digital geospatial datasets are available for download as part of this report by following hyperlinks. The hyperlinks point to FGDC-compliant metadata for the datasets. Links in the Distribution_Information section of the metadata provide access to the download files.

DEM and Derivatives Used by ArcHydro Tools

http://water.usgs.gov/lookup/getspatial?ds680 archydrohucs http://water.usgs.gov/lookup/getspatial?ds680 archydroglobal

\section{Statewide Datasets}

http://water.usgs.gov/lookup/getspatial?ds680 statewidelayers

Original Vector Data Files

http://water.usgs.gov/lookup/getspatial?ds680 originaldata

\section{Summary and Conclusions}

These datasets are used by the Hawaii StreamStats web application, and may be downloaded and used to delineate watersheds, compute basin characteristics, and compute streamflow estimates throughout the State of Hawaii.

\section{Selected References}

Environmental Systems Research Institute, Inc., 2007, Hydro Data Model: Environmental Systems Research Institute, Inc., accessed March 16, 2012, at http:// support.esri.com/index.cfm?fa=downloads.dataModels. filteredGateway\&dmid $=15$.

Environmental Systems Research Institute, Inc., 2011, An overview of Spatial Analyst Toolsets and Tools: Environmental Systems Research Institute, Inc., accessed March 30, 2012, at http://webhelp.esri.com/ arcgisdesktop/9.3/index.cfm?TopicName=An_overview of Spatial_Analyst Toolsets and Tools.

Federal Geographic Data Committee, 1998, Content standard for digital geospatial metadata: Washington, D.C., Federal Geographic Data Committee, 78 p.

Giambelluca, T.W., Nullet, M.A., and Schroeder, T.A., 1986, Rainfall atlas of Hawai'i: State of Hawai'i, Department of Land and Natural Resources, Report R76, 267 p.

Hellweger, Ferdi, and Maidment, David, 1997, AGREE-DEM Surface Reconditioning System: Austin, Tex., University of Texas, Center for Research in Water Resources, accessed February 23, 2012, at http://www.crwr.utexas.edu/gis/ gishyd98/quality/agree/agree.htm.

Homer, C., Huang, C., Yang, L., Wylie, B., and Coan, M., 2004, Development of a 2001 National Landcover Database for the United States: Photogrammetric Engineering and Remote Sensing, v. 70, no. 7, p. 829-840.

Horizon Systems Corporation, 2006, National Hydrography Dataset Plus (NHDPlus): Horizon Systems Corporation, accessed March 16, 2012, at http://www.horizon-systems. com/nhdplus/.

Jenson, S.K., and Domingue, J.O., 1988, Software tools to extract topographic structure from digital elevation data for geographic information system analysis: Photogrammetric Engineering and Remote Sensing, v. 54, no. 11, p. 1,5931,600 .

Johnston, C.M., Dewald, T.G., Bondelid, T.R., Worstell, B.B., McKay, L.D., Rea, Alan, Moore, R.B., and Goodall, J.L., 2009, Evaluation of catchment delineation methods for the medium-resolution National Hydrography Dataset: U.S. Geological Survey Scientific Investigations Report 2009-5233, 88 p. (Also available at http://pubs.usgs.gov/ $\underline{\operatorname{sir} / 2009 / 5233 / .)}$ 
Moore, R.B., Johnston, C.M., Robinson, K.W., and Deacon, J.R., 2004, Estimation of total nitrogen and phosphorus in New England streams using spatially referenced regression models: U.S. Geological Survey Scientific Investigations Report 2004-5012, p. 1-42. (Also available at http://pubs. water.usgs.gov/sir2004-5012.)

Natural Resources Conservation Service, 2008, Watershed Boundary Dataset (WBD): U.S. Department of Agriculture, accessed February 23, 2012, at http://www.nrcs.usda.gov/ wps/portal/nrcs/detail/national/ngmc/?cid=nrcs143 021630 .

Oki, D.S., Rosa, S.N., and Yeung, C.W., 2010, Floodfrequency estimates for streams on Kaua 'i, O'ahu, Moloka`i, Maui, and Hawa`'i, State of Hawai'i: U.S. Geological Survey Scientific Investigations Report 20105035, 121 p. (Also available at http://pubs.usgs.gov/ $\underline{\operatorname{sir} / 2010 / 5035 / .)}$

Perica, S., Martin, D., Lin, B., Parzybok, T., Riley, D., Yekta, M., Hiner, L., Chen, L.-C., Brewer, D., Yan, F., Maitaria, K., Trypaluk, C., Bonnin, G. M., 2009, NOAA Atlas 14, Volume 4, Version 2.1: Precipitation-Frequency Atlas of the United States, Hawaiian Islands, NOAA, National Weather Service, Silver Spring, MD.

Rea, Alan, and Skinner, K.D., 2009, Estimated perennial streams of Idaho and related geospatial datasets: U.S. Geological Survey Data Series 412, 32 p. (Also available at http://pubs.usgs.gov/ds/412/.)

Saunders, William, 2000, Preparation of DEMs for use in environmental modeling analysis, Hydrologic and hydraulic modeling support, in Maidment, D. and Djokic, D., eds., Hydrologic and Hydraulic Modeling Support with Geographic Information Systems: Redlands, Calif., Environmental Systems Research Institute Press, p. 29-51.

U.S. Department of Agriculture, 2003, National SSURGO data: Natural Resources Conservation Service, accessed November 26, 2003 at http://www.ncgc.nrcs.usda.gov/ branch/ssb/products/ssurgo/data/hi.html.
U.S. Environmental Protection Agency and U.S. Geological Survey, 1999, Standards for national hydrography datasetHigh resolution (Draft): U.S. Environmental Protection Agency and U.S. Geological Survey Technical Instructions, accessed February 23, 2012, at http://rockyweb.cr.usgs.gov/ nmpstds/nhdstds.html.

U.S. Environmental Protection Agency, 2001, National Land Cover Data: U.S. Environmental Protection Agency, accessed March 30, 2012, at http://www.epa.gov/mrlc/nlcd2001.html.

U.S Geological Survey, 2005, Elevation Derivatives for National Applications: U.S. Geological Survey database, accessed March 16, 2012, at http://edna.usgs.gov.

U.S. Geological Survey, 2006, National Elevation Dataset: U.S. Geological Survey dataset, accessed March 16, 2012, at http://ned.usgs.gov/.

U.S. Geological Survey, 2007, National Hydrography Geodatabase: U.S. Geological Survey database, accessed March 16, 2012, at http://nhdgeo.usgs.gov.

U.S. Geological Survey, 2008, National Hydrography Dataset: U.S. Geological Survey dataset, accessed March 16, 2012, at http://nhd.usgs.gov.

U.S. Geological Survey, 2008, StreamStats: U.S. Geological Survey website, accessed March 16, 2012, at http:// streamstats.usgs.gov/.

Verdin, K.L., and Worstell, Bruce, 2008, A fully distributed implementation of mean annual streamflow regional regression equations: Journal of the American Water Resources Association, v. 44, no. 6, p. 1,537-1,547. 
Publishing support provided by the U.S. Geological Survey Publishing Network, Tacoma Publishing Service Center

For more information concerning the research in this report, contact the Director, Idaho Water Science Center

U.S. Geological Survey

230 Collins Road

Boise, Idaho 83702

http://id.water.usgs.gov

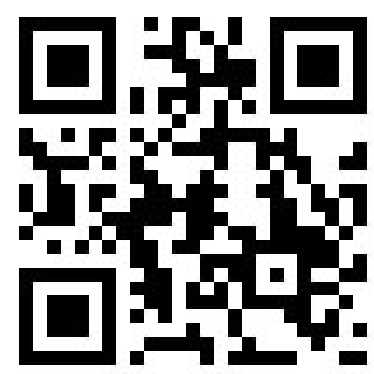


